\title{
PERANCANGAN SISTEM PENDUKUNG KEPUTUSAN UNTUK MENENTUKAN PEMINATAN EKSTRAKURIKULER DENGAN METODE SIMPLE ADDITIVE WEIGHTING (SAW) PADA SISWA MTS N SUMBER KABUPATEN REMBANG BERBASIS WEB
}

\author{
Khuli Handayani, Dhidik Prastiyanto, Sugeng Purbawanto \\ Jurusan Teknik Elektro Universitas Negeri Semarang \\ Kampus Sekaran, Gunungpati, Semarang, 50229, Indonesia \\ e-mail : handayanikhuli@gmail.com, dhidik.prastiyanto@mail.unnes.ac.id, \\ sugengpurbawanto@mail.unnes.ac.id
}

\begin{abstract}
The extracurricular interest process at State MTs of Sumber Rembang has coordination constraint between homeroom teacher and deputy head of the curriculum in the determination of extracurricular interest. It makes the determination process a bit longer. Therefore a decision support system that capable of providing the alternative solution in the extracurricular interest process is needed. The purpose of this study is to create a decision support system which can facilitate the process of determination extracurricular at State MTs Sumber Rembang. The method used in this study was waterfall method. It consists of five steps, those are system analysis, system design, system implementation, system testing and maintenance. System validity is done by using white box testing and testing of system quality with ISO 9126 standard. The white box testing result or test case on the system is valid. The result of this study show that A Decision Support System of Extracurricular Interest Using SAW Method at State MTs of Sumber Rembang Web-based was evidenced to be useful for homeroom teacher, administrator, and extracurricular advisor in the determination extracurricular interest process at State MTs of Sumber Rembang.
\end{abstract}

Keywords: Simple additive weighting (SAW); DSS ; Extracurricular interests

\begin{abstract}
Abstrak
Dalam penentuan peminatan ekstrakurikuler di MTs N Sumber Rembang wali kelas dan waka kurikulum mengalami kendala koordinasi dalam menentukan peminatan ekstrakurikuler sehingga proses peminatan ekstrakurikuler membutuhkan waktu yang agak lama. Terkait hal tersebut maka dibutuhkan suatu sistem pendukung keputusan peminatan ekstrakurikuler yang mampu memberikan solusi alternatif dalam proses peminatan ekstrakurikuler. Tujuan dari penelitian ini adalah untuk menghasilkan sistem pendukung keputusan yang dapat memudahkan MTs N Sumber Rembang dalam menentukan peminatan ekstrakurikuler. Metode yang digunakan dalam mengembangkan sistem adalah metode waterfall dimana tahapantahapan metode tersebut adalah analisis kebutuhan, desain sistem, implementasi sistem, pengujian sistem dan pemeliharaan sistem. Pengujian sistem menggunakan pengujian white box dan pengujian kualitas sistem dengan standar ISO 9126. Hasil yang didapatkan dari pengujian white box atau uji kasus pada sistem menunjukkan masing-masing test case adalah valid. Hasil implementasi dari sistem melalui pengujian kualitas sistem menunjukkan bahwa Sistem Pendukung Keputusan untuk Menentukan Peminatan Ekstrakurikuler Menggunakan Metode SAW Pada Siswa MTs N Sumber Rembang Berbasis Web sangat layak digunakan oleh wali kelas, TU dan pembina ekstrakurikuler dalam menentukan peminatan ekstrakurikuler di MTs N Sumber Rembang.
\end{abstract}

Kata Kunci: Simple additive weighting (SAW); Sistem pendukung keputusan (SPK); Peminatan ekstrakurikuler

Perancangan Sistem Pendukung Keputusan Untuk Menentukan Peminatan Ekstrakurikuler Dengan Metode Simple Additive Weighting (SAW) Pada Siswa Mts N Sumber Kabupaten Rembang Berbasis Web (K. Handayani) 


\section{Pendahuluan}

Sekolah merupakan lembaga pendidikan yang memiliki tanggung jawab untuk memberi pengetahuan, keterampilan dan mengembangkannya dalam bentuk kegiatan sekolah. Dalam pelaksanaannya ada 3 jenis kegiatan kurikuler yang terjadi di sekolah yaitu kegiatan intrakurikuler, kokurikuler dan ekstrakurikuler. Ekstrakurikuler merupakan kegiatan pendidikan diluar jam pelajaran yang ditujukan untuk membantu perkembangan peserta didik sesuai dengan kebutuhan, potensi, bakat, dan minat mereka [1]. Pengembangan kegiatan ekstrakurikuler mengacu pada prinsip partisipasi aktif dan menyenangkan [2]. Fungsi kegiatan ekstrakurikuler adalah membantu pengembangan dan pemantapan kepribadian siswa yang cenderung berkembang untuk memilih jalan tertentu [3].

MTs N Sumber Rembang merupakan sekolah berbasis agama Islam dengan menekankan kepada siswa tentang manajemen waktu dimana siswa boleh mengikuti segala jenis kegiatan ekstrakurikuler dengan tidak mengesampingkan pelajaran reguler maupun diniyah (madrasah sore hari). Proses penentuan ekstrakurikuler di MTs Negeri Sumber Rembang dilakukan oleh pihak sekolah melalui beberapa tahap. Tahap pertama, siswa mengisi angket pada saat diberi waktu pelajaran maupun ekstra (pramuka misalnya) kemudian dikumpulkan kepada wali kelas masing-masing. Tahap kedua, Wali kelas bersama dengan BK (Bimbingan Konseling) dan Waka (Wakil Kepala) Kurikulum berunding dengan mempertimbangkan empat kriteria. Kriteria pertama adalah minat siswa. Kriteria kedua yaitu piagam saat SD ataupun MI. Kriteria ketiga adalah rekomendasi dari guru terkait misalnya dari guru olah raga maupun seni bahwa siswa tersebut berbakat. Sedangkan kriteria ke-empat yaitu jarak rumah. Tahap ketiga, setelah mempertimbangkan empat kriteria diatas, kemudian pihak sekolah mengelompokkan siswa ke dalam ekstrakurikuler sesuai hasil rundingan. Tahap ke-empat, daftar siswa yang mengikuti ekstrakurikuler dicetak dan diumumkan. Kendala yang dialami oleh pihak sekolah untuk menentukan peminatan ekstrakurikuler adalah koordinasi yang agak lama antara wali kelas dengan guru terkait dan Waka kurikulum karena kurangnya komunikasi dikarenakan adanya tugas dan wewenang yang lain selain menangani ekstrakurikuler. Selain itu, proses peminatan siswa dilakukan secara manual sehingga proses peminatan tidak terstruktur dan memerlukan waktu yang relatif lama. Saat ini MTs Negeri Sumber Rembang sedang giat mengembangkan sekolah menjadi lebih maju dalam berbagai bidang. Tahun 2017 ini MTs Negeri Sumber Rembang menjadi satu-satunya sekolah tingkat pertama di kecamatan sumber yang mengadakan UNBK (Ujian Nasional Berbasis Komputer). Dengan adanya perancangan sistem pendukung keputusan peminatan ekstrakurikuler berbasis web di MTs Negeri Sumber Rembang akan menambah pengembangan sekolah di bidang teknologi dan informasi untuk ekstrakurikuler serta menambah kepraktisan pihak sekolah dalam melakukan peminatan ekstrakurikuler. Oleh karena itu, perlu adanya sistem pendukung keputusan peminatan ekstrakurikuler untuk pengambilan keputusan yang tepat bagi siswa. Sistem pendukung keputusan merupakan sistem informasi berbasis komputer yang menggabungkan sumber kecerdasan individu dengan kemampuan komponen dalam proses pengambilan keputusan [4]. Tujuan dari sistem pendukung keputususan yaitu untuk membantu manajer dalam mengambil keputusan, meningkatkan efektifitas kepuasan dan peningkatan produktifitas [5].

Metode yang digunakan dalam sistem pendukung keputusan peminatan ekstrakurikuler adalah metode Simple Additive Weighting (SAW) untuk mencari penjumlahan terbobot dari rating kinerja pada setiap alternatif [6]. Sistem pendukung keputusan peminatan ekstrakurikuler dibuat berbasiskan web. Web merupakan keseluruhan halaman-halaman web dalam sebuah domain yang dibangun atas banyak halaman web yang saling berhubungan [7]. Kelebihan web dari pada media informasi yang lain yaitu mudah diakses dan mudah dalam hal perawatan [8]. Penelitian lain yang dilakukan dengan memanfaatkan Fuzzy MADM For Major Selection at Senior High School telah menyatakan teknik fuzzy MADM dengan motode Simple Additive Weighting (SAW) memberikan hasil yang baik dalam pemilihan jurusan untuk SMA (Sekolah Menengah Atas) yang ditunjukkan berdasarkan prosentase hasil akurasi melalui peminatan secara sempel manual sebesar $60 \%$, sedangkan setelah menggunakan aplikasi sistem pendukung keputusan pemilihan jurusan menunjukkan prosentase akurasi sebesar 90\% [9]. Dilain hal adanya pengembangan peneliti melalui sistem pendukung keputusan penentuan peminatan siswa menunjukkan rerata prosentase hasil sebesar $79,17 \%$ dan hasil ketidakcocokan hasil rekomendasinya sebesar $20,83 \%$ [10]. Penelitian ini merancangan sebuah sistem pendukung keputusan dalam menentukan peminatan ekstrakurikuler dengan mengaplikasikan metode Simple Additive 
Weighting (SAW) pada siswa MTs Negeri Sumber Kabupaten Rembang berbasis web dimana sistem pendukung keputusan tersebut dilakukan melalui peminatan ekstrakurikuker dengan empat kriteria yaitu minat siswa, piagam, rekomendasi dan jarak.

\section{Metode Penelitian}

Model pengembangan sistem yang digunakan dalam penelitian ini adalah model waterfall. Tahapan utama dari model waterfall mencerminkan aktivitas pengembangan dasar [11].

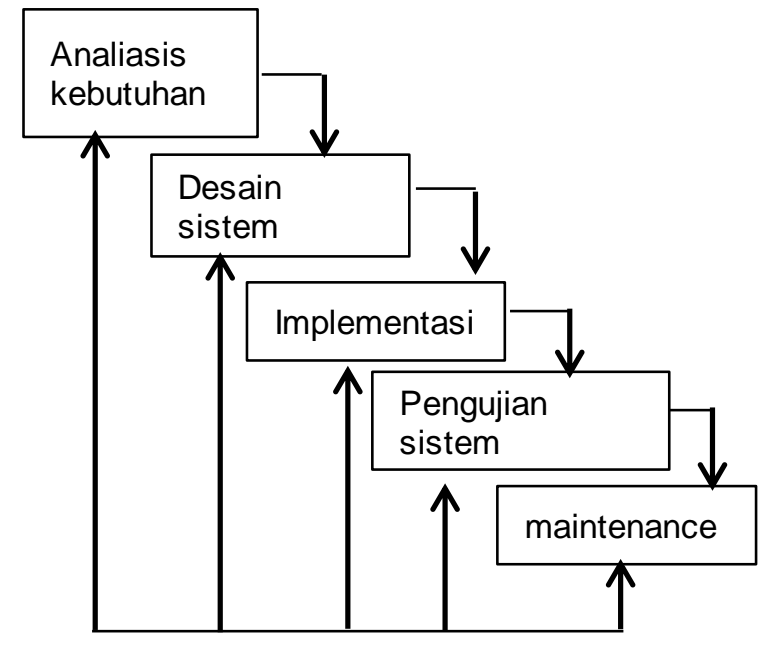

Gambar 1. Model Pengembangan waterfall menurut Sommerville

Penjelasan dari tahapan-tahapan model waterfall menurut sommervile adalah sebagai berikut [11] :

\section{a. Analisis kebutuhan}

Dalam tahapan ini ditetapkan fitur, kendala dan tujuan sistem melalui konsultasi dengan pengguna sistem. Analisis kebutuhan sistem dilakukan dengan mengumpulkan data. Teknik pengumpulan data dilakukan dengan studi kepustakaan, wawancara, dan angket. Studi kepustakaan dilakukan dengan membaca, mempelajari, dan memahami referensi atau literatur yang berhubungan dengan pembuatan sistem pendukung keputusan beserta metode SAW. Studi kepustakaan berasal dari jurnal internasional, jurnal nasional dan buku. Wawancara diajukan kepada waka kurikulum mengenai prosedur peminatan ekstrakurikuler, kriteria yang digunakan dalam proses peminatan ekstrakurikuler, dan ekstrakurikuler apa saja yang ada di MTs Negeri Sumber Rembang. Data yang telah dikumpulkan kemudian dijadikan acuan dalam pembuatan sistem. Selanjutnya angket diberikan untuk mendapatkan data respon dari staf TU, wali kelas, dan pembina ekstrakurikuler mengenai sistem pendukung keputusan ekstrakurikuler.

b. Desain sistem

Dalam tahapan ini dibentuk suatu arsitektur sistem berdasarkan persyaratan yang telah ditetapkan serta menggambarkan abstraksi dasar sistem perangkat lunak dan hubungan-hubungannya. Desain sistem digambarkan dengan menggunakan flowchart, $D F D, E R D$, perancangan database, dan perancangan desain interface.

C. Implementasi

Dalam tahapan ini, hasil dari desain sistem akan direalisasikan sebagai satu set program. Satu set program dibuat dengan menggunakan aplikasi sublime text 2 dan pembuatan database menggunakan MySQL.

d. Pengujian sistem

Dalam tahapan ini, sistem akan diuji sebagai satu sistem yang utuh untuk memastikan sistem sudah memenuhi persyaratan yang ada. Pengujian sistem dilakukan dengan menggunakan te knik white box dan pengujian kualitas sistem menggunakan standar ISO 9126.

e. Pemeliharaan sistem

Setelah sistem selesai diuji, kemudian sistem dipasang dan mulai digunakan. Dalam tahap ini dilakukan pengembangan sistem seperti penambahan fitur dan fungsi baru serta perbaikan error yang tidak ditemukan dalam tahap pembuatan sistem. 
Sedangkan algoritma pembuatan sistem pendukung keputusan menggunakan metode Simple Additive Weighting (SAW). Metode Simple Additive Weighting (SAW) sering juga disebut sebagai metode penjumlahan terbobot. Mencari penjumlahan terbobot dari rating kinerja setiap alternatif pada setiap atribut merupakan konsep dasar dari metode tersebut. Dalam pengambilan keputusan metode ini membutuhkan proses normalisasi matriks keputusan $(X)$ ke suatu skala yang dapat diperbandingkan dengan semua rating alternatif yang ada [12]. Langkah-langkah dalam metode Simple Additive Weighting (SAW) adalah sebagai berikut [13].

1) Menentukan alternatif $\left(A_{i}\right)$.

Alternatif dalam sistem pendukung keputusan peminatan ekstrakurikuler adalah pilihan ekstrakurikuler yang ada di MTs Negeri Sumber Rembang. Alternatif tersebut adalah $A_{1}$ adalah pencak silat, $A_{2}$ adalah sepak bola, $A_{3}$ adalah basket, $A_{4}$ adalah voli, $A_{5}$ adalah lempar lembing, $A_{6}$ adalah lompat jauh, $A_{7}$ adalah futsal, $A_{8}$ adalah tenis meja, $A_{9}$ adalah music band, $A_{10}$ adalah rebana, $A_{11}$ adalah marching band, $A_{12}$ adalah komputer dan $A_{13}$ adalah jahit.

2) Menentukan kriteria $\left(\mathrm{C}_{\mathrm{j}}\right)$ yang akan dijadikan acuan pengambilan keputusan.

Terdapat 4 kriteria yang digunakan yaitu piagam $\left(\mathrm{C}_{1}\right)$, rekomendasi $\left(\mathrm{C}_{2}\right)$, jarak $\left(\mathrm{C}_{3}\right)$, dan minat siswa $\left(\mathrm{C}_{4}\right)$.

3) Memberikan nilai rating kecocokan setiap alternatif pada setiap kriteria.

Dalam perhitungan ini setiap kriteria dihitung menggunakan atribut benefit dari metode Simple Additive Weighting (SWA), yang berarti semakin tinggi nilainya maka akan semakin baik. Contoh kasus peminatan terdapat pada Tabel 1. Ahmad Wahyu Adi Nugroho (berminat pada ekstrakurikuler tenis meja, mempunyai piagam dan rekomendasi ekstrakurikuler tenis meja dan jarak rumahnya dekat dengan sekolah). Tabel hasil peminatan A. Wahyu akan ditampilkan pada Tabel 1 .

Tabel 1. Hasil peminatan

\begin{tabular}{ccccc}
\hline Kriteria & \multicolumn{5}{c}{ Alternatif } \\
\cline { 2 - 5 } & $\mathrm{C}_{1}$ & $\mathrm{C}_{1}$ & $\mathrm{C}_{1}$ & $\mathrm{C}_{1}$ \\
\hline $\mathrm{A}_{1}$ & 0 & 0 & 1 & 0 \\
\hline $\mathrm{A}_{2}$ & 0 & 0 & 1 & 0 \\
\hline $\mathrm{A}_{3}$ & 0 & 0 & 1 & 0 \\
\hline $\mathrm{A}_{4}$ & 0 & 0 & 1 & 0 \\
\hline $\mathrm{A}_{5}$ & 0 & 0 & 1 & 0 \\
\hline $\mathrm{A}_{6}$ & 0 & 0 & 1 & 0 \\
\hline $\mathrm{A}_{7}$ & 0 & 0 & 1 & 0 \\
\hline $\mathrm{A}_{8}$ & 1 & 1 & 1 & 1 \\
\hline $\mathrm{A}_{9}$ & 0 & 0 & 1 & 0 \\
\hline $\mathrm{A}_{10}$ & 0 & 0 & 1 & 0 \\
\hline $\mathrm{A}_{11}$ & 0 & 0 & 1 & 0 \\
\hline $\mathrm{A}_{12}$ & 0 & 0 & 1 & 0 \\
\hline $\mathrm{A}_{13}$ & 0 & 0 & 1 & 0 \\
\hline & & & &
\end{tabular}

4) Menentukan bobot preferensi (W) pada setiap kriteria.

$$
W=\left[W_{1}, W_{2}, \ldots W_{J}\right]
$$

Bobot setiap kriteria mempunyai nilai yang berbeda sesuai dengan prioritas kriteria yang ada di sekolah. Bobot setiap kriteria mempunyai dua pilihan. Pilihan untuk kriteria piagam dan rekomendasi adalah iya dengan nilai bobot 5, dan tidak dengan nilai bobot 0 . Pilihan untuk kriteria jarak adalah dekat dengan nilai bobot 2 , dan jauh dengan nilai bobot 0 . Pilihan untuk kriteria minat adalah iya dengan nilai bobot 6 , dan tidak dengan nilai bobot 0 . Setelah didapatkan nilai bobot dari masing-masing kriteria, kemudian dilakukan proses normalisasi. Normalisasi bertujuan agar nilai bobot antar kriteria tidak memiliki kesenjangan nilai terlalu tinggi dan bersifat normal. Dari hasil normalisasi tersebut akan digunakan pada tahap selanjutnya [14]. Berikut merupakan formula untuk menormalisasi nilai bobot pada masing-masing kriteria. 


$$
\text { Bobot ternormalisasi }=\frac{\text { Bobot }}{\sum \text { Bobot }}
$$

Hasil nilai bobot ternormalisasi pada tiap-tiap kriteria dapat disajikan pada Tabel 2.

Tabel 2. Tabel hasil nilai bobot ternormalisasi

\begin{tabular}{ccc}
\hline No & Kriteria & Bobot \\
\hline 1 & $\mathrm{C}_{1}$ & 0,28 \\
\hline 2 & $\mathrm{C}_{2}$ & 0,28 \\
\hline 3 & $\mathrm{C}_{3}$ & 0,11 \\
\hline 4 & $\mathrm{C}_{4}$ & 0,33 \\
\hline
\end{tabular}

5) Membuat tabel rating kecocokan dari setiap alternatif pada setiap kriteria. Tabel rating kecocokan akan disajikan pada Tabel 3.

Tabel 3. Tabel rating kecocokan

\begin{tabular}{lllll}
\hline Alternatif & \multicolumn{4}{c}{ Kriteria } \\
\cline { 2 - 5 } & C1 & C2 & C3 & C4 \\
\hline A1 & 0 & 0 & 0,11 & 0 \\
\hline A2 & 0 & 0 & 0,11 & 0 \\
\hline A3 & 0 & 0 & 0,11 & 0 \\
\hline A4 & 0 & 0 & 0,11 & 0 \\
\hline A5 & 0 & 0 & 0,11 & 0 \\
\hline A6 & 0 & 0 & 0,11 & 0 \\
\hline A7 & 0 & 0 & 0,11 & 0 \\
\hline A8 & 0,28 & 0,28 & 0,11 & 0,33 \\
\hline A9 & 0 & 0 & 0,11 & 0 \\
\hline A10 & 0 & 0 & 0,11 & 0 \\
\hline A11 & 0 & 0 & 0,11 & 0 \\
\hline A12 & 0 & 0 & 0,11 & 0 \\
\hline A13 & 0 & 0 & 0,11 & 0 \\
\hline
\end{tabular}

6) Membuat matriks keputusan $(X)$ yang berasal dari tabel rating kecocokan setiap alternatif setiap kriteria menggunakan persamaan (3).

$$
\begin{aligned}
\mathrm{X} & =\left[\begin{array}{cccc}
x_{11} & x_{12} & \cdots & x_{1 j} \\
\vdots & & & \vdots \\
x_{i 1} & x_{i 2} & \cdots & x_{i j}
\end{array}\right] \\
X & =\left\{\begin{array}{cccc}
0 & 0 & 0,11 & 0 \\
0 & 0 & 0,11 & 0,33 \\
0 & 0 & 0,11 & 0 \\
0 & 0 & 0,11 & 0 \\
0 & 0 & 0,11 & 0 \\
0 & 0 & 0,11 & 0 \\
0 & 0 & 0,11 & 0 \\
0,28 & 0,28 & 0,11 & 0,33 \\
0 & 0 & 0,11 & 0 \\
0 & 0 & 0,11 & 0 \\
0 & 0 & 0,11 & 0 \\
0 & 0 & 0,11 & 0 \\
0 & 0 & 0,11 & 0
\end{array}\right\}
\end{aligned}
$$


7) Melakukan normalisasi keputusan ( $X$ ) dengan menghitung nilai rating kinerja ternormalisasi ( $\mathrm{rij})$ setiap alternatif pada kriteria $\left(\mathrm{C}_{\mathrm{j}}\right)$.

$$
r_{i j}=\left\{\begin{array}{c}
\frac{x_{i j}}{\operatorname{Max}_{i}\left(x_{i j}\right)} \\
\frac{\operatorname{Min}_{i} x_{i j}}{x_{i j}}
\end{array}\right.
$$

8) Hasil dari nilai rating kinerja membentuk matriks ternormalisasi $(R)$.

$$
\mathrm{R}=\left[\begin{array}{cccc}
r_{11} & r_{12} & \cdots & r_{1 j} \\
\vdots & & & \vdots \\
r_{i 1} & r_{i 2} & \cdots & r_{i j}
\end{array}\right]
$$

9) Melakukan penjumlahan dan perkalian elemen baris matriks ternormalisasi dengan bobot preferensi untuk memperoleh hasil akhir nilai preferensi $\left(\mathrm{V}_{\mathrm{i}}\right)$.

$$
\mathrm{V}_{\mathrm{i}}=\sum_{\mathrm{j}=1}^{\mathrm{n}} \mathrm{w}_{\mathrm{j}} \mathrm{r}_{\mathrm{ij}}
$$

Tabel untuk hasil perkalian matriks normalisasi dengan nilai bobot terdapat pada Tabel 4 dibawah ini :

Tabel 4. Hasil perkalian matriks normalisasi dengan nilai bobot

\begin{tabular}{lc}
\hline Alternatif & Perhitungan \\
\hline A1 & $\left(0^{\star} 0,28\right)+\left(0^{\star} 0,28\right)+\left(1^{\star} 0,11\right)+\left(0^{\star} 0,33\right)=0,11$ \\
\hline A2 & $\left(0^{\star} 0,28\right)+\left(0^{\star} 0,28\right)+\left(1^{\star} 0,11\right)+\left(0^{\star} 0,33\right)=0,11$ \\
\hline A3 & $\left(0^{\star} 0,28\right)+\left(0^{\star} 0,28\right)+\left(1^{\star} 0,11\right)+\left(1^{\star} 0,33\right)=0,44$ \\
\hline A4 & $\left(0^{\star} 0,28\right)+\left(0^{\star} 0,28\right)+\left(1^{\star} 0,11\right)+\left(0^{\star} 0,33\right)=0,11$ \\
\hline A5 & $\left(0^{\star} 0,28\right)+\left(0^{\star} 0,28\right)+\left(1^{\star} 0,11\right)+\left(0^{\star} 0,33\right)=0,11$ \\
\hline A6 & $\left(1^{\star} 0,28\right)+\left(1^{\star} 0,28\right)+\left(1^{\star} 0,11\right)+\left(1^{\star} 0,33\right)=1$ \\
\hline A7 & $\left(0^{\star} 0,28\right)+\left(0^{\star} 0,28\right)+\left(1^{\star} 0,11\right)+\left(0^{\star} 0,33\right)=0,11$ \\
\hline A8 & $\left(0^{\star} 0,28\right)+\left(0^{\star} 0,28\right)+\left(1^{\star} 0,11\right)+\left(0^{\star} 0,33\right)=0,11$ \\
\hline A9 & $\left(0^{\star} 0,28\right)+\left(0^{\star} 0,28\right)+\left(1^{\star} 0,11\right)+\left(0^{\star} 0,33\right)=0,11$ \\
\hline A10 & $\left(0^{\star} 0,28\right)+\left(0^{\star} 0,28\right)+\left(1^{\star} 0,11\right)+\left(0^{\star} 0,33\right)=0,11$ \\
\hline A11 & $\left(0^{\star} 0,28\right)+\left(0^{\star} 0,28\right)+\left(1^{\star} 0,11\right)+\left(0^{\star} 0,33\right)=0,11$ \\
\hline A12 & $\left(0^{\star} 0,28\right)+\left(0^{\star} 0,28\right)+\left(1^{\star} 0,11\right)+\left(0^{\star} 0,33\right)=0,11$ \\
\hline
\end{tabular}

Alternatif terbaik $\left(A_{i}\right)$ didapatkan dengan hasil perhitungan $V_{i}$ dengan nilai terbesar [13]. Setelah didapatkan hasil diatas, kemudian dilakukan perankingan. Hasil perankingan menunjukkan siswa atas nama A. Wahyu Adi mendapatkan alternatif terbaik dengan nilai akhir 1 pada ektrakurikuler tenis meja.

\section{Hasil dan Pembahasan}

Sistem pendukung keputusan peminatan ekstrakurikuler mampu melakukan perhitungan secara otomatis tanpa harus mengubah koding jika terdapat penambahan kriteria dan bobot. Implementasi penambahan kriteria beserta perhitungannya dapat dilihat pada Gambar 2-5. 
Jurnal IImu Teknik Elektro Komputer dan Informatika (JITEKI)

Vol. 4, No. 1, Juni 2018

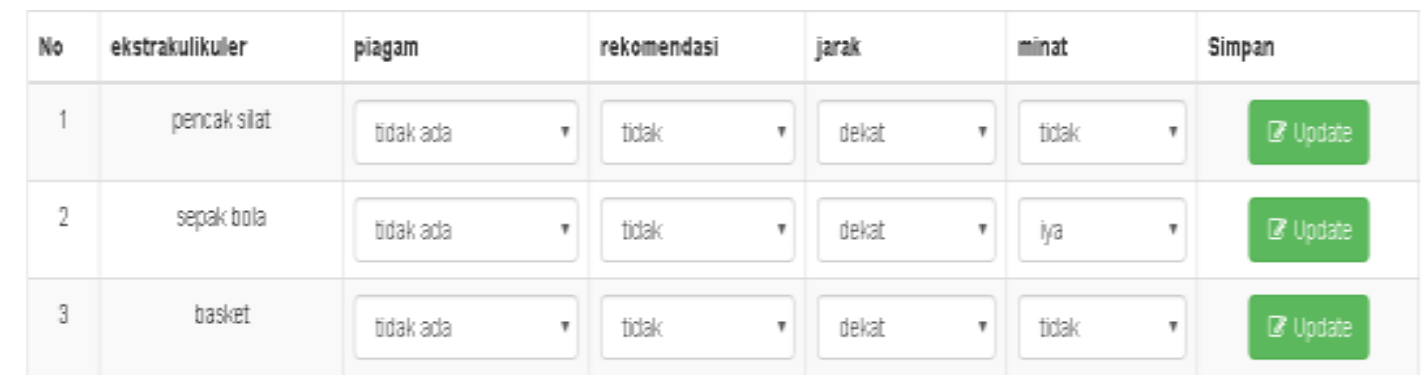

Gambar 2. Gambar sistem dengan menggunakan 4 kriteria

Gambar 2 merupakan tampilan sistem ketika menggunakan 4 kriteria. Admin dapat melakukan update data apabila terjadi kesalahan dalam memasukkan data. Jika terdapat penambahan kriteria persetujuan orang tua, tampilan sistem akan berubah menjadi seperti pada Gambar 3 berikut.

\begin{tabular}{|c|c|c|c|c|c|c|c|c|c|c|c|c|}
\hline No & ekstrakulikuler & piagam & & rekomer & & jarak & & minat & & orang tua & & Simpan \\
\hline 1 & pencak siat & tidak ada & , & todak & , & dekat & , & tidak & , & Setuj」 & , & E Latste \\
\hline 2 & sepak bola & tidak ada & ' & tidak & , & dekat & ' & ya & , & Edak & , & Z Uptate \\
\hline 3 & basket & tijak acla & ' & bidak & , & dekat & ' & tidak & , & tdak & , & Z Utokte \\
\hline
\end{tabular}

Gambar 3. Gambar sistem dengan menggunakan 3 kriteria

Pada Gambar 3 menampilkan sistem dengan 5 kriteria. Setelah memasukkan data, sistem kemudian melakukan perhitungan seperti pada Gambar 4 dan Gambar 5 berikut.

\begin{tabular}{|c|c|c|c|}
\hline A. WAHVU ADO NUGROHO & pencak stat & piagam & D \\
\hline A. WhEMU ADE NUGROHO & pencaki siat & retinmendasi & 0 \\
\hline A WAHYU ACO FUGROHO & pencak slat & jarak & a.111111111111 \\
\hline A WAHW ADU NUGRCHO: & pencaksust & minst & D \\
\hline A. WHHYU AD NUGROHO & sepak bota & piagam & D \\
\hline A. WAHYU ADC NUGFOHO & sepaic bota & relivmendasi & 0 \\
\hline A. WUETU ACENUGPCHO & sepaicbala & jarak & 0.11111111111111 \\
\hline A WAHMU ADE NUGRCHO & sepak bola & minat & 0. 33333333333333 \\
\hline A. WAHYU AOC RJGROHO & basper & piagen & 0 \\
\hline A. WAHVU AD NUGROHO & bashet & refornendasi & 0 \\
\hline A. WAHW ADU NUGRCHO & basset & laras & 0.5111411111111 \\
\hline A. WWHY AD NUGRCHO & bashet & minat & D \\
\hline
\end{tabular}

Gambar 4. Gambar hasil perhitungan sistem dengan menggunakan 4 kriteria

Gambar 4 menampilkan hasil perhitungan dengan menggunakan 4 kriteria, perhitungan dilakukan dengan metode Simple Additive Weighting (SAW) menggunakan bobot yang telah ditentukan. Selanjutnya, jika terdapat penambahan kriteria, sistem akan melakukan perhitungan tanpa mengubah koding yang akan ditampilkan pada Gambar 5 berikut. 


\begin{tabular}{|c|c|c|c|}
\hline A. WHATU AOI NUGROHO & pencak silat & piagam & 0 \\
\hline A. Whatru AOI HUGRCHO & pencak:silat & rekonendasi & 0 \\
\hline A WUHFV ACI NUGRCAO & pencak silat & jarak & 0.090909090909091 \\
\hline A. WWHVU ADI NUGRCHO & pencak sillat & $\min a t$ & 0 \\
\hline A WHHYU ADI NUGROHO & sepak bcla & plagam & 0 \\
\hline A WAHTU ADI MUGRCHO & sepak bcla & reksmendasi & 0 \\
\hline A. WAHYVU ADI NUGROHO & sepax buia & jarak: & 0.090909090909091 \\
\hline A. WHAHUADINUGROHO & sepak odla & minat & 0.27272727272727 \\
\hline A WAHTV AOI NUGPCHO & basket & piagam & 0 \\
\hline A WAHYU AOI NUGRCHO & basket & rekomendasi & 0 \\
\hline A WAHTVU AOI NUGRCHO & basket & jask & 0.090909090909091 \\
\hline A. WHAHVU AOH NUGROHO & basket & minz: & 0 \\
\hline A. WAHYU ADI NUGROHO & pencak silat & orang tua & 0.18181818181818 \\
\hline A. WAHYU ADI NUGROHO & sepak bola & orang tua & 0 \\
\hline A. WAHYU ADI NUGROHO & basket & orang tua & 0 \\
\hline
\end{tabular}

Gambar 5. Gambar perhitungan sistem dengan menggunakan 5 kriteria ditentukan.

Gambar 5 menampilkan perhitungan menggunakan 5 kriteria dan bobot yang telah

\subsection{Hasil Pengujian White Box}

Pengujian white box merupakan salah satu cara untuk menguji aplikasi dengan melihat modul dan menganalisa kode dari program yang telah dibuat [15]. Salah satu jenis pengujian white box adalah statement coverage. Statement coverage merupakan sebuah teknik white box yang memastikan setiap executable statements dijalankan satu kali [16]. Perbandingan perhitungan manual dan menggunakan sistem ditunjukkan pada Gambar 6 dan Gambar 7.

$$
\begin{aligned}
& \text { A1 }=(0,28 * 0)+(0,28 * 0)+(0,11 * 0)+(0,33 * 0)=0 \\
& \text { A2 }=(0,28 * 0)+(0,28 * 0)+(0,11 * 0)+(0,33 * 0)=0 \\
& \text { A3 }=(0,28 * 0)+(0,28 * 0)+(0,11 * 0)+(0,33 * 0)=0 \\
& \text { A4 }=(0,28 * 0)+(0,28 * 0)+(0,11 * 0)+(0,33 * 0)=0 \\
& \text { A5 }=(0,28 * 0)+(0,28 * 0)+(0,11 * 0)+(0,33 * 0)=0 \\
& \text { A6 }=(0,28 * 0)+(0,28 * 0)+(0,11 * 0)+(0,33 * 0)=0 \\
& \text { A7 }=(0,28 * 0)+(0,28 * 0)+(0,11 * 0)+(0,33 * 0)=0 \\
& \text { A8 }=(0,28 * 0)+(0,28 * 0)+(0,11 * 0)+(0,33 * 0)=0 \\
& \text { A9 }=(0,28 * 0)+(0,28 * 0)+(0,11 * 0)+(0,33 * 0)=0 \\
& \text { A10 }=(0,28 * 0)+(0,28 * 0)+(0,11 * 0)+(0,33 * 0)=0 \\
& \text { A1 }=(0,28 * 0)+(0,28 * 1)+(0,11 * 0)+(0,33 * 1)=0,61 \\
& \text { A12 }=(0,28 * 0)+(0,28 * 0)+(0,11 * 0)+(0,33 * 1)=0,33 \\
& \text { A13 }=(0,28 * 0)+(0,28 * 0)+(0,11 * 0)+(0,33 * 0)=0
\end{aligned}
$$

Gambar 6. Gambar perhitungan manual

Pada Gambar 6 ditampilkan gambar hasil dari perhitungan manual setiap alternatif dengan menggunakan 4 kriteria. Setelah itu, dilakukan pengujian terhadap sistem dengan memasukkan data sesuai dengan data yang digunakan pada proses perhitungan manual. Hasil perhitungan yang dilakukan oleh sistem dapat dilihat pada Gambar 7. 


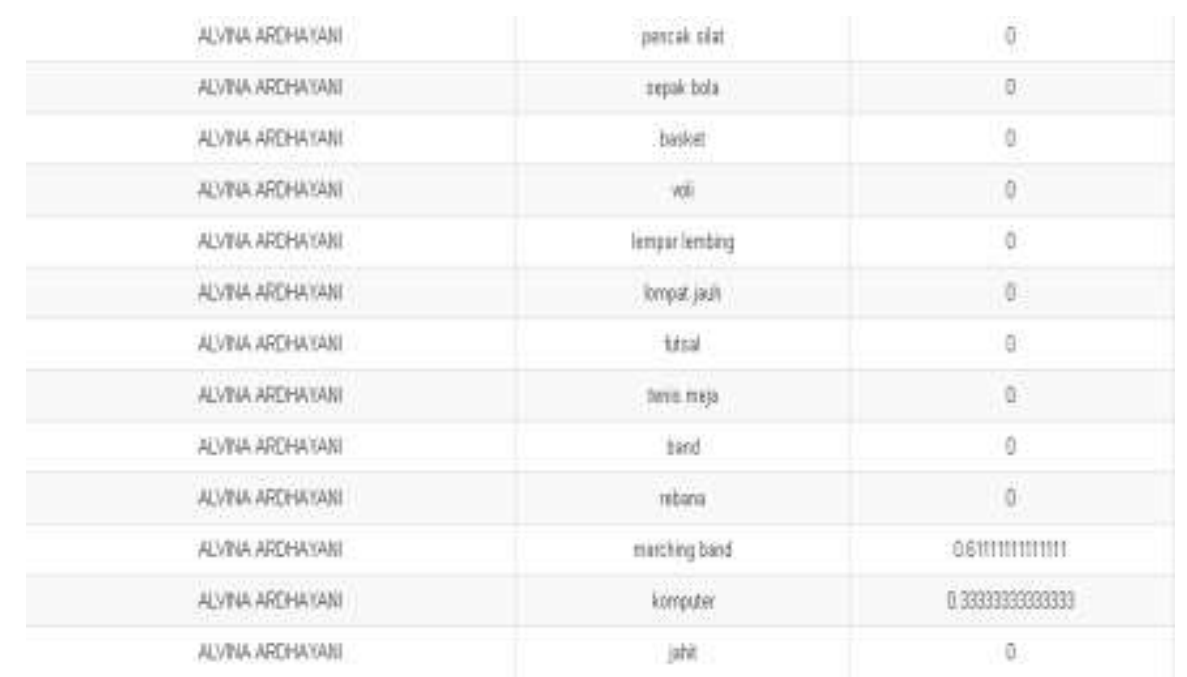

Gambar 7. Gambar perhitungan menggunakan sistem

Gambar 7 menampilkan hasil perhitungan dari sistem. Hasil perhitungan tersebut sama dengan hasil perhitungan manual. Berdasarkan White box testing yang telah dilakukan, didapatkan kecocokan hasil $100 \%$ valid. Hal tersebut menandakan bahwa sistem pendukung keputusan peminatan ekstrakurikuler MTs Negeri Sumber Rembang yang sudah dibuat sudah berjalan dengan baik sesuai dengan fungsi - fungsi yang diharapkan.

\subsection{Hasil Uji Kualitas Sistem ISO 9126}

Pengujian dilakukan dengan cara membagikan angket yang berisikan 17 pertanyaan kepada 6 responden yang terdiri dari 2 orang TU, 2 orang Wali Kelas dan 2 orang Pembina Ekstrakurikuler.Selanjutnya untuk mendapatkan presentase dari masing-masing butir pertanyaan tersebut didapatkan dengan rumus skala likert sebagai berikut. Hasil rekapitulasi pengujian kualitas sistem ditunjukkan pada Tabel 5.

$$
\text { kelayakan }(\%)=\frac{\text { skor yang diobervasi }}{\text { skor maksimal }} \times 100 \%
$$

Tabel 5. Tabel hasil rekapitulasi pengujian kualitas sistem standar ISO 9126

\begin{tabular}{|c|c|c|c|}
\hline No & Aspek & $\begin{array}{c}\text { Skor } \\
\text { Kelavakan \% }\end{array}$ & Kategori \\
\hline 1 & Fungsionalitas & 87,5 & SL \\
\hline 2 & Reliabilitas & 85,47 & SL \\
\hline 3 & Usabilitas & 89,29 & $S L$ \\
\hline 4 & Keefisienan & 79,17 & L \\
\hline 5 & Portabilitas & 91,67 & SL \\
\hline 6 & Efektifitas & 87,5 & SL \\
\hline 7 & Kepuasan & 83,33 & SL \\
\hline Rat & lata & 87,75 & SL \\
\hline
\end{tabular}

Berdasarkan Tabel 5 dapat dilihat bahwa pada aspek fungsionalittas memiliki prosentase $87,5 \%$ (sangat layak) yaitu sistem dapat melakukan perankingan dengan metode Simple Additive Weighting (SAW), aspek reliabilitas 85,47\% (sangat layak) karena jika terjadi kesalahan terdapat pemberitahuan, aspek usabilitas $89,29 \%$ (sangat layak) hal ini karena sistem sederhana, mudah dipahami, dipelajari dan dioperasikan. Pada aspek keefisienan 79,1\% (layak) yang berarti kecepatan respon dan pengolahan data sistem memerlukan waktu yang relatif singkat. Untuk aspek portabilitas $91,67 \%$ (sangat layak) dimana sistem dapat berjalan pada 
browser berbasis dekstop, sedangkan aspek efektifitas 87,5\% (sangat layak) hal ini karena sistem dapat memberikan peminatan ekstrakurikuler dengan tepat sesuai dengan kriteria yang telah ditentukan dan hasil pemiatan ekstrakurikuler sama dengan hasil peminatan yang sudah berjalan.Kemudian pada aspek kepuasan 83,33\% (sangat layak) karena secara keseluruhan kinerja sistem memberikan hasil yang memuaskan. Secara keseluruhan aspek sistem pendukung keputusan peminatan ekstrakurikuler di MTs Negeri Sumber Rembang memiliki prosentase $87,75 \%$ yang menunjukkan sistem sangat layak untuk digunakan.

\section{Kesimpulan}

Berdasarkan hasil penelitian dan pembahasan sistem pendukung keputusan pada penelitian ini dapat disimpulkan bahwa sistem sangat layak digunakan berdasarkan pengujian sistem dengan standar ISO 9126 dan mendapatakan prosentase kelayakan 87,75\% serta dibuktikan dengan hasil pengujian white box menunjukkan prosentase keberhasilan $100 \%$. Kelebihan dari sistem ini adalah sistem mampu untuk melakukan perhitungan secara otomatis tanpa harus mengubah source code jika terdapat penambahan kriteria dan bobot.

\section{Referensi}

[1] Noor Yanti, Rabiatul A. Pelaksanaan Kegiatan Ekstrakurikuler dalam Rangka Pengembangan Nilai-Nilai Karakter Siswa untuk Menjadi Warga Negara yang Baik Di SMA Kopri Banjarmasin. Jurnal Pendidikan Kewarganegaraan. 2016; Vol.6, No.11.

[2] Peraturan Menteri Pendidikan Dan Kebudayaan Republik Indonesia No.62 Tahun 2014. Kegiatan Ekstrakurikuler Pada Pendidikan Dasar dan Pendidikan Menengah.

[3] Hamditika, A. Zakso. Fungsi Kegiatan Ekstrakurikuler dalam Meningkatkan Integrasi Sosial Siswa SMA Negeri 1 Segodong. Jurnal: FKIP UNTAN. 2013.

[4] Wiwit Supriyanti. Rancang Bangun Aplikasi Sistem Pendukung Penerima Beasiswa dengan Metode SAW. Citec Journal. 2013; Vol.1, No.1, ISSN: 2354-5771.

[5] Hetty Rohayani. Analisis Sistem Pendukung Keputusan dalam Memilih Program Studi Menggunakan Metode Logika Fuzzy. JSI. 2013; Vol.5, No.1, e-ISSN: 2355-4614.

[6] Melisa Elistri, Jusuf Wahyudi. Penerapan Metode SAW dalam Sistem Pendukung Keputusan Pemilihan Jurusan Pada Sekolah Menengah Atas Negeri 8 Seluma. Jurnal Media Infotama. 2014; Vol.10, No.2, ISSN 1858-2680.

[7] Heldiansyah, Rahma Indera. Pengembangan Sistem Informasi Penjualan Alat Kesehatan Berbasis Web Pada PT. Alfin Fanca Prima. Jurnal POSITIF. 2015; Tahun I, No. 1: 37-45

[8] Anggit Dwi Hartanto, Yudha Wirawan S. Analisis dan Perancangan Sistem Informasi Simpan Pinjam Di Koperasi KOPMA UGM Menggunakan Framework Codeigniter. Jurnal DASI. 2012; Vol.13, No.2, ISSN: 1411-3201.

[9] Fata NK, Adhistya EP. Fuzzy MADM for Major Selection at Senior High Shcool. IEEE Information Technology, Computer and Electrical Engineering (ICITACEE). 2015.

[10] Fairuz Saniyya. Sistem Pendukung Keputusan Penentuan Peminatan Siswa Pada SMA Negeri 1 Bojong. Yogyakarta. AMIKOM YOGYAKARTA; 2016.

[11] Mia Rosmiati. Analisis Dan Perancangan E-Service untuk Pelanggan Pada Jaya Bersama Konveksi. IJSE. 2015; Vol. 1, No. 1, ISSN: 2461-0690.

[12] Akhmad Sanusi. Sistem Pendukung Keputusan Dengan Metode Fuzzy SAW Untuk Penilaian Kinerja Dosen Politeknik Harapan Bersama Tegal. Jurnal: Universitas Dian Nuswantoro. 2015.

[13] Nugroho. Sistem Pendukung Keputusan Penilaian Proses Belajar Mengajar Menggunakan Metode Simple Additive Weighting (SAW). Semarang. Universitas Diponegoro; 2013.

[14] Firdausa, Aji Prasetya W. Model Sistem Pendukung Keputusan Pemilihan Sekolah Menggunakan Metode SAW. Seminar Nasional Teknologi Informasi dan Multimedia. 2016.

[15] Sarita Pathy, Santosh Panda. A Review on Code Coverage Analysis. IJCSET. 2015; Vol. 6, No.10, ISSN: 2229-3345.

[16] M. Sidi Mustaqbal, Roeri Fajri F. Pengujian Aplikasi Menggunakan Black Box Testing Boundary Value Analysis (Studi Kasus : Aplikasi Prediksi Kelulusan SNMPTN). Jurnal JITTER. 2015; Vol.1, No. 3, ISSN : 2407-3911. 